\title{
ARE CORPORATE UNIVERSITIES (CU) POSSIBLE IN EMERGING COUNTRIES? A SURVEY CONDUCTED IN ARGENTINA SHOWED \\ IMPACTING RESULTS
}

\author{
Dr. Leandro A. Viltard \\ Buenos Aires University, UBA, Argentina \\ E-mail: Iviltard@yahoo.com.ar
}

Submission: 22/12/2013

Revision: 06/01/2014

Accept: 17/01/2014

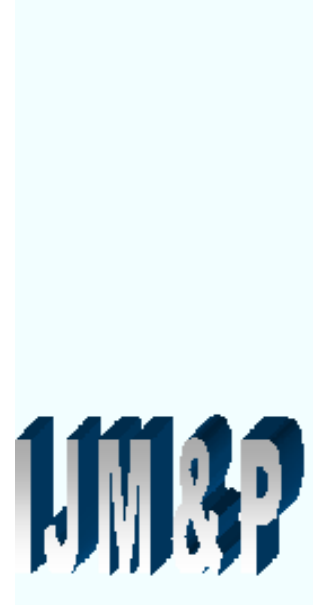

\section{ABSTRACT}

At the time of our investigation, the $\mathrm{CU}$ was not a widespread concept in Argentina, being viewed as a "foreign - far long project" (coming from developed countries and standing for the long term).

It is suggested that the rate of $\mathrm{CU}$ evolution, in emerging countries like Argentina, is more related to mentality issues than to $\mathrm{CU}$ strategic or operative limitations. Although the executives who replied to a survey were not the only power factor in their organization, their comments allow us to think that, in those countries, the CU may have a better future perspective.

The research used a quali-quantitative methodology, which was based on a survey to top executives of different kinds of companies located in Argentina. The research design was not experimental and transversal, as it was limited to a specific moment in time.

Keywords: Corporate University, Corporate education and training, Emerging countries, Developing countries, Argentina, Corporate University Implementation 

ISSN: 2236-269X

DOI: 10.14807/ijmp.v5i3.181

\section{INTRODUCTION}

Corporate Training (CT) has its origins in Traditional Universities (TU), moving then to other environments. Therefore, in the early $20^{\text {th }}$ century, the occurrence was observed of a particular phenomenon known as the Corporate University (CU). Its great development in recent years has shown it as a disruption in higher education, comparable only with e-learning. Thus, the CU defies known educational terms, setting new limits, and areas for development (DEALTRY, 2000).

As a result, TUs and CUs have constantly redefined their roles in terms of institutions, teachers, students and educational proposals.

There are over 3,000 CUs worldwide, and some experts suggest that, in a few years, their number will exceed that of TUs, and also in terms of quantity of students. These facts highlight the great responsibility the $\mathrm{CU}$ has in front of more demanding students who are searching for educational proposals with a direct impact on their profession (EL-TANNIR, 2002).

Over time, CU goals have changed, but have always offered educational and practical help, improving their students' skills.

Today we see that CUs have different purposes, from being considered as agent of change and dissemination of culture and values, to being the liaison with the organization's strategy. It covers the entire value chain, from employees to customers, suppliers and, sometimes, a wider arch of stakeholders. Its final objective is to offer strategic learning and adapted skills to processes and products, focusing on productivity and performance (WEINSTEIN, 2007).

The main hypothesis of this investigation considered that $\mathrm{CU}$ implementation in Argentina lagged due to mentality issues, but its feasibility and evolution possibilities are not limited to developed and emerging countries, company's origin, or specific industries.

\subsection{Design: Methodology \& Analysis}

Our analysis was based on a specially designed survey, which was compiled and sent by email to top executives of companies located in Argentina, in order to ascertain their implementation possibilities. 
The study was exploratory and descriptive. It used a quali-quantitative methodology, with a qualitative predominance. Its design was not experimental and transversal, as the information was collected at a given moment in time.

The unit of analysis was firms with implemented CUs. The criterion for the sample selection was not probabilistic, it was intentional and directed. We tried to ensure that prior knowledge did not hinder either the selection of the companies that were circularized or the analysis of the answers given.

The sample size was 60 companies (110 were circularized, but 60 answered). The criterion for analysis was defined as companies with activities in Argentina, with or without an implemented CU. The nature of these companies varied by industrial sector, headquarters location, size (measured in terms of quantity of employees and revenues), and countries in which they operate (national or international arena). Being a quali-quantitative research, the sample size has not been limited.

The respondents were the CEOs and top executives who received the survey. This survey was conducted in Argentina between Jan. 2009 - May. 2012.

\subsection{Research Limitations/Clarifications}

- We have used information from relevant secondary sources worldwide, although we recognize that it is very difficult to ascertain that all relevant information has been included.

- The selected companies were chosen intentionally considering industry and origin. The proportion of Argentinean companies included in the sample was much greater than worldwide companies. As already mentioned, this was because the objective of the research was to emphasize the CU phenomenon in Argentina.

- Doing a survey with open and closed questions and only a "final comments" request could limit the respondents' information, but it was deemed the best way to approach as many busy companies' executives as we intended to. 
- We used the survey to collect information from the field, not using a triangulation with other data collection techniques to better assure the results of this investigation. ${ }^{1}$

- It should be noted that some companies' executives have not answered all the questions as they were referred to as confidential and/or sensitive data. Additionally, Oracle Argentina has not responded to the survey despite having a CU located in USA, because their executives cannot reveal any data on this project. However, valuable information was obtained through other sources (website and inquiries to stakeholders). The objectives were to better support and confirm the appropriateness of what was presented in this paper.

- Not to undermine the content and the investigation purpose, the conclusions and opinions that are expressed in this review are strictly based on the information obtained from the survey.

We understand that a reasonable valid sample was analyzed and a thorough investigation on CUs was performed in order to help us to conclude on CU possibilities in Argentina. As a qualitative investigation we hope it will help in the decision making process (DEALTRY, 2012).

\subsection{Findings}

This investigation showed that in emerging countries like Argentina, the CU was not widespread implemented due to mentality and old dominant logic reasons. Crisis management and other priorities had a better consideration in executives' agenda than longer projects like the $\mathrm{CU}$, but executives of companies, with and without a CU implemented in their firms, understood its value and benefits.

\footnotetext{
${ }^{1}$ For further assurance on conclusions and results, please refer to "Are Corporate Universities (CU) possible in emerging countries?, Arcor University" (2014), Independent Journal of management \& Production.. In this article we analyzed the case of Grupo Arcor CU and interviewed specialists that help to understand this phenomenon with a wider perspective.
} 


\subsection{Originality and Value}

This was the first CU survey conducted for companies located in Argentina. An in-depth understanding of this management process and its implementation possibilities will provide the opportunity to enhance the educational ecosystem and the individual long term employment.

\subsection{WHY IS THE CU SO IMPORTANT?}

CUs have changed the rules of the CT game. The present investigation has its main motivations from the great challenges and opportunities arising from $\mathrm{CT}$, which are based on factors like:

- The largest number of people who have joined the workforce.

- The obsolescence of knowledge, which highlights the importance of continuous learning and knowledge management, and their influence on the growth of businesses and individuals.

- The loss of boundaries between TU and CU, creating situations to resolve issues including teachers, staff and students.

- The university curricula are massified and standardized; making it difficult to differentiate between training offers.

- The gap between theory and practice has deepened, complicating the ability to translate what happens from classrooms to companies.

- The new technological tools have allowed the dissemination of content, although unevenly.

- The emergence of new providers and educational solutions has set higher standards for the education market.

\subsection{Investigation Objective}

The objective is to assist in CU study and implementation, determining its feasibility in Argentinean companies and probably, emerging countries.

\subsection{The Survey: Approach}

The survey included 18 questions in total: 12 closed and 6 open, and in addition the possibility of final open comments to enrich the research. The questions cover topics such as whether the CU was or not implemented in those organizations; the objectives and reasons for its creation; the major capabilities that were to be 
developed in students; number of personnel involved (staff, faculty and students); benefits of its implementation and future possibilities, ways of imparting education (classroom, online or mixed), among others. In the case of those companies that responded that they had not implemented a $\mathrm{CU}$, we asked why, and if it sought to implement it in the next two years. In addition, we asked if they had a TCTD and the benefits that had when comparing it with the $\mathrm{CU}$ concept.

This survey was sent via email to the main executives of the sampled companies (Presidents, CEOs, Vice Presidents, Directors and Managers Human Resources UC), as we understood that the $\mathrm{CU}$ should be a primary responsibility of top management. Upon receipt, replies were analyzed as discussed below.

The surveyed firms should have their headquarters ( $\mathrm{HQ}$ ) or a branch in Argentina, and take leadership in their markets (further information is shown in Attachment I - In-depth sample analysis).

\subsection{The Survey: Results}

The survey analysis was organized in two groups of companies, the ones with a $\mathrm{CU}$ and the others without. Its purpose was to reveal if there were common patterns in these groups and conclude on CU potentialities in Argentina.

For the firms without a CU, we won't reveal the company's name and/or executive who replied as the only intention of this paper is to take advantage of replies and new insights possibilities.

\section{COMPANIES WITH AN IMPLEMENTED CU}

Out of the 60 responses, there were a total of 22 companies $(36.7 \%)$ which indicated that had a $\mathrm{CU}$ implemented, as follows: Accenture, Arcor Group, Cap Gemini, Danone, HSBC, IBM, Intel, Master Card/Argencard, Monsanto, Oracle Corp., PepsiCo International, Sun Microsystems, The Walt Disney Co., Unilever, Repsol/YPF, Wal Mart, Tenaris, Banco Santander Rio, American Express, CocaCola, Kraft Foods and Microsoft. A further analysis showed the following:

The 22 companies (100\%) were dealing in the international arena.

By origin: 13 cases (59\%) belonged to USA, 7 cases (32\%) to EU and 2 cases $(9 \%)$ to Argentina. 
By industry: 6 cases (27.3\%) mass consumption, 5 cases $(22.7 \%)$ IT and Telcos, 3 cases $(13.6 \%)$ financial services, 2 cases $(9.1 \%)$ consulting, 1 case $(4.5 \%)$ entertainment, 1 case $(4.5 \%)$ agriculture, 1 case $(4.5 \%)$ retail, 1 case $(4.5 \%)$ air navigation, and the remaining (4.5\%) energy.

Their annual global revenue ranged from M\$ 2,300 (Grupo Arcor, Argentina) to $M \$ 422,000$ (Wal Mart, USA) and the total number of employees from 5,100 (Master Card-Argencard, USA) to 2,100,000 (Wal Mart).

Eleven cases identified the year of CU inception: Accenture (2006), Grupo Arcor (2007), Cap Gemini (80), Pepsi Cola International (2006), HSBC (2004), Intel (2006), IBM (beginning of the $20^{\text {th }}$.century), The Walt Disney Co ('70), Wal Mart (2007), Tenaris (2005) and Banco Santander Rio (2005).

The most frequent reasons given for implementation were linked to the need for a central space for learning; dissemination of knowledge and culture; developing a company's sense of belonging; promotion of a discussion forum and common language for business; competitive advantage creation and maintenance and, finally, the education and training of internal and external people.

Respondents have suggested that an additional CU benefit was to develop and transfer global business visions throughout the entire organization. They understand that this is needed to understand the organization's environment, and link it with classroom education and daily tasks. In addition to and according to the surveyed executives, the $\mathrm{CU}$ could benefit strategic, business and operational development.

It was verified that the CUs were located in the company's HQ, except IBM which had peripheral locations worldwide. Generally, when the $\mathrm{CU}$ is in the company $H Q$, it assures understanding, acceptance, dissemination and stronger commitment to policies and strategies within the organization.

In all cases, educational methods used were mixed (classroom and online), as a way to reach as many students as it was possible. As a consequence, course availability and flexibility are a must.

A total of 21 firms $(95,5 \%)$ informed that they had agreements with TU (except for the case of Unilever who didn't reply to this question). We can see that 
INDEPENDENT JOURNAL OF MANAGEMENT \& PRODUCTION (IJM\&P)

http://www.ijmp.jor.br

v. 5, n. 3, June - September 2014

ISSN: 2236-269X

DOI: 10.14807/ijmp.v5i3.181

these agreements are common and new boundaries are possible for both types of institutions.

The students who participated in CU training varied. In some cases, this only included employees; others also included external associates (clients, vendors and distributors). Since 2003, Cap Gemini trained employees and clients in their CU located in Paris and Banco Santander Rio trained customers on subjects like small companies. In fewer cases, this included external non-associates (like Disney University, that trained students who were not related with the company, obtaining revenues for that).

Replies showed that Grupo Arcor trained 900 employees a year with 30 teachers and 6 staff; Intel 100,000 employees with 1.680 teachers; Unilever 1,500 employees per year; Master Card/Argencard had 15 staff (not giving the quantity of students and professors); The Walt Disney Co. 42,000 people per year and Tenaris had 110 staff, 2,000 teachers and 1,000 employees in the world who had completed at least a CU course and 23,500 employees who took a course once a year $(93 \%$ of all employees). In addition, Oracle University trained 320,000 students annually (their total employees were 80,000 , so this included were students who did more than one course a year). As a conclusion, the CU had a widespread scope and is not only directed to employees, but in certain cases, to related and non-related external public.

The replies received demonstrated that there were different training areas: Business global vision and excellence; Strategic management and market trends; Management and talent development; Innovation, leadership, entrepreneurship and negotiation; Sales and technical/specific areas; Government. With the exception of "technical/specific areas" development, all the topics were referred to as soft skills, as they are the basic skills needed in the current business world.

There were 21 companies (100\%) which replied that the CU was in line with the objectives of the company. Oracle Corp. has not answered, although it is possible to assume that, if they had, the answer would have been positive, too. This response is confirmatory and what could be expected, since it would be impossible create a $\mathrm{CU}$ with no strict alignment to the strategy and objectives of the firm. 
As it was reported, the main benefits of implementing a CU were referred to as soft skills, as per the following detail:

- Aid to business strategy and innovation.

- International network expansion, and also, to actual and future business.

- Connection between the business model and the human resources.

- Helps in the dissemination of culture, open-mindedness and important content within the organization.

- Allows the transfer of knowledge and synergies; cost savings and operational improvements.

These benefits illustrate that CUs are not limited only to training and conventional education, but broaden the horizons and possibilities of each organization into strategic and innovation issues (DEALTRY, 2003; DEALTRY, 2004).

A total of 18 companies replied positively to the question on CU self-financing. Only 2 of them, PepsiCo International and Intel, reported that their CU was not selfsufficient and we think that this was possibly because they have recently implemented it. In addition, Intel replied that not profit was pursued because of their corporate social responsibility policy.

All 18 companies said that they would continue with their $\mathrm{CU}$ in the future, so it appears that self-financing wouldn't be a problem.

As a result, it was clear that those companies with a CU could feel its benefits and transfer them to the context in which they operate. Attachment II, Companies with an implemented CU, shows some details on these firms GARY; MEISTER, 1998).

\section{COMPANIES WITHOUT AN IMPLEMENTED CU}

A total of 38 companies (63\% of the 60 companies that replied) didn't have a CU and, also, did not intend to implement it in the next two years. In 2009 one firm (2\% of the 60 companies) would begin its development (Colcar Merbus -Argentina, Mercedes Benz official representative which employed 
INDEPENDENT JOURNAL OF MANAGEMENT \& PRODUCTION (IJM\&P)

http://www.ijmp.jor.br

v. 5, n. 3, June - September 2014

ISSN: 2236-269X

DOI: 10.14807/ijmp.v5i3.181

180 people. Its objective was to complement the German parent training programs).

The 38 cases analysis showed the following:

The most diverse origins: USA 11 cases (29\%), EU 11 cases (29\%), Argentina 15 cases (39\%) and Mexico 1 case (3\%).

A total of 27 companies (71\% of the 38 cases) were operating internationally.

Diverse industries and companies' sizes, examples: American Express (financial services, 1,000 employees in Argentina), Gador Laboratories (pharmaceutical, 683 employees in Argentina), Gas Natural Fenosa Group (energy, 6,843 total employees), Pan American Energy (oil, 1,800 employees in Argentina and Bolivia), Peugeot-Citroen (automotive, 201,000 employees worldwide), Telecom (telecommunications, 14,000 employees in Argentina), Telmex (telecommunications, 700 employees in Argentina), Tetra Pack (industry, 21,000 employees worldwide) and Zurich (insurance, 58,000 employees worldwide and 500 in Argentina).

The remaining 11 companies (29\% of the 38 cases) were dealing only in the local market and all of them were Argentinean.

Out of the 38 companies without a CU, 30 (79\%) had a TCTD, $3(7.9 \%)$ did not answer this question and $5(13.1 \%)$ did not have a TCTD.

One question referred to was whether or not the $\mathrm{CU}$ improves the TCTD training context. We got 7 positive responses (18.4\%), 17 negative $(44.7 \%)$ and 14 non-respondents (36.8\%). It appeared that the CU was not a widespread practice in Argentina, maybe a reason why it was difficult to break with traditional thinking patterns.

Of these 38 companies, 22 of them (81.5\%) had 500 or more employees. Two cases (7.5\%, Gas Natural Fenosa Group and Telecom Argentina), were operating in non-competitive markets, while the rest didn't. Six cases (27\%) were dealing only in the local market: Banco Galicia (500 employees), OSDE (3,500), Swiss Medical Group (6,600), Unitan (540), Coto $(18,000)$ and Roemmers Lab. $(1,100)$. 
INDEPENDENT JOURNAL OF MANAGEMENT \& PRODUCTION (IJM\&P)

http://www.ijmp.jor.br

v. 5, n. 3, June - September 2014

ISSN: 2236-269X

DOI: 10.14807/ijmp.v5i3.181

Attachment II - Companies without an implemented CU shows greater detail of these firms.

According Lewis (2005), below there are eleven reasons why a CU had not been implemented, as per the replies given by companies' top executives, and also our comments:

1. Implementation difficulties due to business and organizational characteristics: It seems that there were businesses/industries/organizations in which skills development could be unacceptable.

2. No alignment with corporate culture: Corporate culture must be linked to the mission, vision, policies, and also with educational excellence, to improve the competitive position. In this respect, the $\mathrm{CU}$ can offer a vital contribution. Additionally, it could a better tool to effectively disseminate corporate culture and leadership.

3. Education and training is not our core business: There is not a unique way to put together business activities and it depends on how top management defines core and support activities. In this way, what should be considered core business is relative to each organizational context; each firm operates depending on particular visions and characteristics. Following this strictly, no firm should maintain activities that are not within their core business, as per the following examples: accounting and payment (for every company), marketing or strategy (for manufacturing companies) and manufacturing (for marketing firms). If the last two examples were followed undesirable risks could arise.

4. Costs and risks to spending the committed budget, assuming there could be no training needed: Are those companies taking decisions based on real needs or on budgets that were approved? Furthermore, spending budgets assuming there were no training needs leads us to believe that there weren't new ideas in the pipeline, thereby damaging future growth. The budget could be an excellent tool to help many organizations on growth opportunities and the CU could have a central role in this environment. 
5. Access difficulty to the best teachers / resources: It is impossible to say that Argentina didn't offer a suitable valid educational context that could support the corporate environment. In our opinion, a pending task for many was related with making the corporate and the traditional educational environments closer through the right partners from both sides.

6. CU functions are partially supplied: Although our research emphasis relates to the benefits of implementing a $\mathrm{CU}$, as it homogenizes the educational programs offered, we can also appreciate the positive value of carrying out initiatives with TU and teachers/specialists as interim solutions if it will then lead to a CU implementation.

Some surveyed companies replied that they had agreements with TU and consultants as they didn't have an implemented CU. It would be acceptable to think that for every problem there is a partial, temporary or progressive solution that allows testing the ground before launching a definite solution (we don't know if this was the case for the two companies that replied in this way). The obvious disadvantage with this alternative is that the $\mathrm{CU}$ functions remained scattered in different areas of the organization and under different executives, making an overall and homogenized approach to training policies and synergies more difficult.

7. Availability of good training in the market: Are there firms that find good training in the market and other that don't? (See prior point 5 discussed). The same arguments shown in point 6 are applicable in this case: content homogenization and definitive solutions are what we recommend.

8. On-the-job training: This kind of training is a partial approach as it is only related with tasks that an individual currently performs. CUs could help linking actual status to the company's and individual future growth.

9. Decentralized training is used according to business needs: There were successful decentralized training proposals (IBM was a case as $\mathrm{HQ}$ common patterns are scattered, as standard, in all locations), but 
we highlight centralization as it can improve synergies and homogenization of culture, objectives, communication and content. In this way, the CU may combat isolated or sporadic solutions.

10. Other priorities, for example, managing crisis: "Crisis" and "urgent priorities" were not new or unexpected hazards for the corporate landscape. Crisis has been among us for a long period of time and we don't know how long it will take to get rid of it. Thus, survival, connected with executives' mentality and firm's financing, retards SMEs business growth in developing countries. A broader view on corporate training is necessary and its connection with strategic objectives, change, culture and values imperative. Transformational projects do not only belong to developing countries or large companies.

11. The firm has a TCTD: Unfortunately, we do not have further details on this response. In our opinion, the name, TCTD or CU, is not the problem, what we emphasize is how deep the function is performed and its added value to the organization. $\mathrm{CU}$-as a comprehensive management function- is our recommendation (DEALTRY, 2012).

As a result of the prior eleven replies, the following table summarizes the main issues that justify a CU as a new alternative in CT:

Table 1: CU positive and negative signs.

\begin{tabular}{ll}
\hline \multicolumn{1}{c}{ Positive signs } & Negative signs \\
\hline $\begin{array}{l}\text { New ideas development and } \\
\text { acceptance. }\end{array}$ & $\begin{array}{l}\text { Budgets don't help the } \\
\text { organizational design and } \\
\text { control, or future projects. }\end{array}$ \\
$\begin{array}{l}\text { Change can be turned into } \\
\text { tangible results. }\end{array}$ & $\begin{array}{l}\text { Partial, sporadic and } \\
\text { disjointed solutions, not } \\
\text { creating a homogeneous } \\
\text { and centralized environment. }\end{array}$ \\
$\begin{array}{l}\text { Identity support with and "Crisis" and priorities" } \\
\text { purpose, mission and } \\
\text { values. mentality. } \\
\begin{array}{l}\text { Knowledge and core } \\
\text { business development. }\end{array}\end{array}$ \\
\hline
\end{tabular}

Source: Own

The final part of the survey referred to final open comments, which, for companies without a $\mathrm{CU}$ implemented, were all positive, except for one firm that understood the $\mathrm{CU}$ to be a drain on resources. All comments received are shown in the following table: 
Table 1: Executives' comments

\begin{tabular}{l}
\hline \multicolumn{1}{c}{ Comments } \\
\hline Umbrella for organization requirements, mentoring and \\
career planning. \\
Culture and knowledge diffuser. \\
Interesting tool for balancing skills and enhance \\
corporate performance. \\
Enables collaboration and lessons' sharing. \\
Develops resources throughout the value chain \\
Interesting tool, better than TCTD. \\
This project must be analyzed not to dilute other \\
priorities. \\
Interesting concept for companies whose size and \\
working groups may warrant a CU. Also, for companies \\
in certain sectors or R\&D centers or regionally. \\
Extraordinary networking.
\end{tabular}

\section{CONCLUSIONS}

Source: Own

There were not many $\mathrm{CU}$ implementations in Argentina and it seems that emerging countries might present additional inconveniences on these kinds of projects, when compared with developed countries. As a result, emerging countries face complex and competitive situations which hamper growth and the competitive environment. The lack of this kind of project was surely related to:

- The industrial under-development and insufficient long term and productive investment.

- Mentalities tied to preconceptions.

- High business relationship with political powers and

- Management's constraints regarding the setting of ambitious goals.

It was observed that the $\mathrm{CU}$ was related to the organizational size, the international markets performance and the industry competitiveness.

The CU highlights the need for a more specific and soft educational content, motivated by volatility and knowledge obsolescence.

\subsection{Companies with an implemented CU}

These companies played in the international arena, belonging to different industrial sectors and employing +500 employees. This investigation shows that competing and growing in the current global context necessarily involves employees' 
CT and that there are no specific industries where the CU could be applicable, only a correspondence with a certain company size to justify synergies.

The CU was developed near to company headquarters to facilitate understanding and commitment to the policies, strategies and projects promoted by top management.

Executives indicated that the $\mathrm{CU}$ was understood as a central place for learning and discussing business issues, spreading knowledge and culture, and developing a sense of organizational belonging. Also, they viewed the $\mathrm{CU}$ as valid for training internal and external stakeholders, and to develop the required competitive advantage.

In general, the CU developed soft skills, but also offered courses for specific technical areas and particular issues.

Agreements with TU and independent professors/specialists were a reality.

Most of the students were employees and, in a few cases, this extended to the near-related (suppliers, distributors, strategic partners). There have been few cases that offered programs to external unrelated audiences, emphasizing $\mathrm{CU}$ financial independence (Disney University is a case).

All companies responded that CUs were self-financing, except for two cases where CUs were recently implemented and one of these was pursuing corporate social responsibility.

We foresee that, if the $\mathrm{CU}$ is encouraged to seek self-financing, the connections with business schools will be increasingly narrowed.

\subsection{Companies without an implemented CU}

As companies with a CU, the group without it showed that its implementation was not related to their origins, size or specific industry, but to dealing in international markets. After our review, we can conclude that the $\mathrm{CU}$ is not more widespread in Argentina because it is seen as a long term investment and power factors are not aligned with growth and operative contributions.

The eleven points analyzed, from the answers given by the executives of this group of companies, showed that the CU had a justification and a need. 
Many of the organizations that replied to the survey were facing market and economic problems. It may be the fact that some organizations are not paying attention to what their employees suggest and/or that some leaders are connected with old practices which could make change and new opportunities very difficult. Change and reinvention is in the realm of everyone's participation and contribution, thus the CU appears to be an excellent vehicle to foster unexplored ways of sustainable growth.

Sporadic or isolated replies like contracted professors or programs are not a definitive reply to CT as it is very difficult to shape growth and market volatility through third parties' resources.

As a result, in our opinion, mentality and a dominant logic, tied to old patterns, influence the acceptance and implementation of long term new projects in emerging countries, like Argentina. Nevertheless, and based on executives' responses, the $\mathrm{CU}$ appears to be an applicable and valid management practice for this environment, although this couldn't influence the final implementation decision. Finally, throughout this investigation the hypothesis was confirmed and the objectives verified.

\section{REFERENCES}

ALLEN, M. (2002). The Corporate University Handbook. Broadway, New York: Amacom.

LEWIS, C. (2005). Corporate universities and Business schools. The Times, 10/02/2005. United Kingdom.

DEALTRY, R. (2004). European Corporate Academies Transnational Best Practice Network. Journal of Workplace Learning: Employee Counseling, n. 16, p. 293301.

DEALTRY, R. (2003). The new generation of corporate universities - co-creating sustainable enterprise and business development solutions. Journal of Workplace Learning, v. 15, n. 7/8, p.368-381, ISBN: 9781904481096.

DEALTRY, R. (2012). The Corporate University Blueprint Handbook. Dynamic SWOT Associates, Birmingham, ISBN: 9781904481270

DEALTRY, R. (2000). Strategic directions in the management of the corporate university paradigm. Journal of Workplace Learning: Employee Counselling Today, v. 12, n. 4, p.171-175, ISBN: 9780952300731

EL-TANNIR, A. (2002). The corporate university model for continuous learning, training and development. Education + Training, n. 44, p. 76-81.

GARY, L. Y.; MEISTER, J. (1998). Corporate Universities: The new pioneers of management education. Harvard Management Update, n. 3, p.10. 
MEISTER, J. (1998). Corporate Universities: The new pioneers of management education. Boston: Harvard Business Publishing Newsletters.

VILTARD, L. a. (2013). Universidad Corporativa: Origen, configuración del mercado de capacitación corporativa y beneficios de su creación, B.S. Lab, Avelino, Italia.

VILTARD, L. A. (2013). Globalización: Entender el nuevo ámbito mundial y tomar decisiones. B. S. Lab, Avelino, Italia.

WEINSTEIN, M. (2007). Corporate University Excellence: Creating a robust and flexible workforce. Best Practices, n. 44, p. 42.

\section{Attachment I: In-depth sample analysis}

\section{International or national scope}

Out of the 60 sampled firms, 52 of them $(87 \%)$ had an international scope, while $8(13 \%)$ operated only in Argentina.

International examples: International: Accenture, American Airlines, BBVB-French Bank, Danone, Dow Chemical, Urano Editors, Fiat Group, Gas Natural Fenosa Group, IBM, Kellogg, Kimberley Clark, Korn Ferry International, Monsanto, Nestlé, Nike, PepsiCo International, Pfizer Laboratories , Price Waterhouse Coopers, Telecom.

National examples: La Caja, Bio Sidus Lab., Molinos Rio de la Plata, Coto Supermarket, Swiss Medical Group.

\section{Origin}

The 60 companies had different origins, understanding who their shareholders were at the moment of the survey. Most of the selected firms (43 cases, $71 \%$ ) had their origins in USA and EU. In addition, a total of 16 cases $(27 \%)$ had an Argentinean origin, 8 of which act internationally.

Some examples (not mentioned before):

- USA: Argencard/Master Card, Deloitte, Hay Group, Intel, Kraft Foods, Microsoft, Productos de Maíz, Sun Microsystems.

- EU: Banco Santander Río, Capgemini, HSBC, Peugeot/Citroën, Repsol/YPF, Tetra Pack, Unilever, Zurich Insurance.

- Argentina: Arcor Group, La Nación, Gador Lab., OSDE. 
- Mexico: Telmex.

\section{Industrial sector}

When viewing the 60 companies distributed by industrial sector, we observe the following: 15 of them (25\%) correspond to consulting services, $12(20 \%)$ to consumer products, $10(17 \%)$ to IT and Telcos, 7 (11\%) financial and insurance, 9 $(15 \%)$ to industry, $4(7 \%)$ to laboratories and $3(5 \%)$ to automotive.

Some examples (not mentioned previously):

- Consulting Services: Michael Page, Russell Reynolds, Stanton Chase.

- Massive consumption: Coca Cola, Procter \& Gamble, Wal Mart.

- IT and Telcos: Oracle, Sktec.

- Finance and Insurance: Galicia Bank, Chase Manhattan Bank.

- Laboratory: Boheringer, Pharmacia, Themis Lostaló, Bayer, Bio Sidus.

- Automotive: Colcar Merbus (Mercedes Benz Dealer), Fiat Group.

- Industry \& Manufacturing (including agriculture, energy and manufacturing): Salentein, Unitán, Ostrillon, Parmalat, Tenaris.

- Energy: Pan American Energy, Pecom. 
INDEPENDENT JOURNAL OF MANAGEMENT \& PRODUCTION (IJM\&P)

http://www.ijmp.jor.br

v. 5, n. 3, June - September 2014

ISSN: 2236-269X

DOI: 10.14807/ijmp.v5i3.181

Attachment II: Companies with an implemented $\mathrm{CU}^{2}$

\begin{tabular}{|c|c|c|c|c|c|c|c|c|}
\hline Empresa & Scope & Origin & $\begin{array}{c}\text { Industrial } \\
\text { Sector }\end{array}$ & $\begin{array}{c}\text { Tot. Rev. } \\
\text { M\$ }\end{array}$ & $\begin{array}{c}\text { Tot. } \\
\text { employees }\end{array}$ & $\begin{array}{c}\text { CU } \\
\text { Start } \\
\text { (year) }\end{array}$ & $\begin{array}{c}\text { Agreements } \\
\text { signed }\end{array}$ & $\begin{array}{c}\text { Self-- } \\
\text { financing }\end{array}$ \\
\hline $\begin{array}{l}\text { Accenture } \\
\text { American }\end{array}$ & INT. & EU & Consulting & 25300 & 211000 & 2006 & Yes & $\mathrm{N} / \mathrm{R}$ \\
\hline $\begin{array}{l}\text { Airlines } \\
\text { Banco }\end{array}$ & INT & USA & Airlines & $\begin{array}{c}23600 \\
1075\end{array}$ & $\begin{array}{c}10000 \\
5300\end{array}$ & NC & Yes & Yes \\
\hline Santander Rio & INT & EU & Bank & (ARG) & (ARG) & 2005 & Yes & Yes \\
\hline Capgemini & INT. & EU & $\begin{array}{l}\text { Consulting } \\
\text { Mass }\end{array}$ & 12400 & 90000 & '80 & Yes & Yes \\
\hline Coca Cola & INT & USA & $\begin{array}{c}\text { Consumption } \\
\text { Mass }\end{array}$ & 115000 & 90000 & NC & Yes & Yes \\
\hline Danone & INT. & EU & $\begin{array}{c}\text { Consumption } \\
\text { Mass }\end{array}$ & 14000 & 80976 & $\mathrm{~N} / \mathrm{C}$ & Yes & Yes \\
\hline Grupo Arcor & INT. & ARG & Consumption & 2300 & 20000 & 2007 & Yes & Yes \\
\hline HSBC & INT. & EU & Bank & 98918 & 296000 & 2004 & Yes & Yes \\
\hline IBM & INT. & USA & IT & 103600 & 400000 & $1900 s$ & Yes & Yes \\
\hline Intel & INT. & USA & $\begin{array}{c}\text { IT } \\
\text { Mass }\end{array}$ & 34000 & 80000 & 2006 & Yes & No \\
\hline $\begin{array}{l}\text { Kraft Foods } \\
\text { M. Card- }\end{array}$ & INT & USA & $\begin{array}{l}\text { Consumption } \\
\text { Financial }\end{array}$ & 29000 & 90000 & NC & Yes & Yes \\
\hline Argencard & INT. & USA & Services & 4900 & 5100 & $\mathrm{~N} / \mathrm{C}$ & Yes & Yes \\
\hline Microsoft & INT & USA & IT & 60420 & 93000 & NC & Yes & Yes \\
\hline Monsanto & INT. & USA & Agriculture & 10500 & 21400 & NC & Yes & Yes \\
\hline Oracle Corp. & INT. & USA & $\begin{array}{c}\text { IT } \\
\text { Mass }\end{array}$ & 35000 & 80000 & $\mathrm{~N} / \mathrm{C}$ & Yes & Yes \\
\hline PepsiCo Int. & INT. & USA & Consumption & 43000 & 104000 & 2006 & Yes & No \\
\hline $\begin{array}{l}\text { Repsol-YPF } \\
\text { Sun }\end{array}$ & INT. & EU & Energy & 60920 & 33000 & $\mathrm{~N} / \mathrm{C}$ & Yes & Yes \\
\hline $\begin{array}{l}\text { Microsystems } \\
\text { Techint / }\end{array}$ & INT. & USA & IT & 11070 & 35000 & $\mathrm{~N} / \mathrm{C}$ & Yes & $N / R$ \\
\hline $\begin{array}{l}\text { Tenaris } \\
\text { The Walt }\end{array}$ & INT & ARG & Industrial & 26000 & 53000 & 2005 & Yes & Yes \\
\hline Disney Co. & INT. & USA & $\begin{array}{c}\text { Entertainment } \\
\text { Mass }\end{array}$ & 38000 & 135600 & 1970 s & Yes & Yes \\
\hline Unilever & INT. & EU & Consumption & 45000 & 55000 & $\mathrm{~N} / \mathrm{C}$ & $N / R$ & Yes \\
\hline Wal Mart & INT. & USA & Retail & 422000 & 2100000 & 2007 & Yes & Yes \\
\hline
\end{tabular}

$\mathrm{N} / \mathrm{R}=\mathrm{Not}$

replied

\footnotetext{
${ }^{2}$ All the information referred to the fiscal year prior to the survey. These vary in accordance with each firm's balance sheet closing. In the majority of the cases, the information related to 2008-2009 years.
} 
INDEPENDENT JOURNAL OF MANAGEMENT \& PRODUCTION (IJM\&P)

http://www.ijmp.jor.br

v. 5, n. 3, June - September 2014

ISSN: 2236-269X

DOI: 10.14807/ijmp.v5i3.181

Attachment III: Companies without an implemented CU 3

\begin{tabular}{|c|c|c|c|c|c|c|c|c|c|}
\hline \multirow[b]{2}{*}{ Company } & \multirow[b]{2}{*}{$\begin{array}{c}\text { Origi } \\
n\end{array}$} & \multirow[b]{2}{*}{ Scope } & \multirow{2}{*}{$\begin{array}{c}\text { Industrial } \\
\text { Sector }\end{array}$} & \multicolumn{2}{|c|}{ Revenue (in M\$) } & \multicolumn{2}{|c|}{ Employees } & \multirow[t]{2}{*}{$\begin{array}{l}\text { Had a } \\
\text { TCTD? }\end{array}$} & \multirow[t]{2}{*}{$\begin{array}{c}\text { Impro } \\
\text { ve the } \\
\text { conte } \\
\text { xt }\end{array}$} \\
\hline & & & & Total & Argentina & $\begin{array}{c}\text { Tota } \\
\text { I }\end{array}$ & $\begin{array}{c}\text { Argen } \\
\text { tina }\end{array}$ & & \\
\hline American & & & Financial & & & 5800 & & & \\
\hline $\begin{array}{l}\text { Express } \\
\text { Banco }\end{array}$ & USA & INT & Svcs. & 29962 & & $\begin{array}{c}0 \\
1120\end{array}$ & 1000 & Yes & No \\
\hline $\begin{array}{l}\text { Francés } \\
\text { Banco }\end{array}$ & EU & INT & $\begin{array}{c}\text { Bank } \\
\text { Financial }\end{array}$ & & 618 & 00 & 4100 & Yes & No \\
\hline Galicia & ARG & NAC & Svcs. & 250 & 250 & $\begin{array}{c}500 \\
1080\end{array}$ & 500 & Yes & No \\
\hline $\begin{array}{l}\text { Bayer } \\
\text { Belise }\end{array}$ & EU & INT & Lab. & 46750 & & 00 & & Yes & $N / R$ \\
\hline Group & ARG & NAC & Consulting & 1,8 & 1,8 & 15 & 15 & No & $N / R$ \\
\hline $\begin{array}{l}\text { Bio Sidus } \\
\text { Chase }\end{array}$ & ARG & NAC & Lab. & 40 & 40 & $\begin{array}{c}380 \\
1432\end{array}$ & 380 & Yes & No \\
\hline $\begin{array}{l}\text { Bank } \\
\text { Colcar }\end{array}$ & USA & INT & Bank & 58716 & & 16 & & Yes & Yes \\
\hline Merbus SA & ARG & NAC & Automotive & 170 & 170 & $\begin{array}{c}180 \\
1800\end{array}$ & 180 & Yes & Yes \\
\hline $\begin{array}{l}\text { Coto } \\
\text { Dow }\end{array}$ & ARG & NAC & $\begin{array}{l}\text { Retail } \\
\text { Petro }\end{array}$ & 3440 & 3440 & $\begin{array}{c}0 \\
6000\end{array}$ & 18000 & Yes & No \\
\hline Chemicals & USA & INT & chemistry & 55000 & 1000 & 0 & 1600 & Yes & Yes \\
\hline $\begin{array}{l}\text { Gador } \\
\text { Gas }\end{array}$ & ARG & INT & Lab. & & & 683 & 683 & Yes & $N / R$ \\
\hline $\begin{array}{l}\text { Natural } \\
\text { Gruppo }\end{array}$ & EU & INT & Gas-Energy & 19233 & 160 & $\begin{array}{l}6842 \\
1370\end{array}$ & 573 & Yes & No \\
\hline Fiat & EU & INT & Automotive & 45000 & & 00 & & Yes & No \\
\hline $\begin{array}{l}\text { Hay Group } \\
\text { Korn Ferry }\end{array}$ & USA & INT & Consulting & & & 2600 & & Yes & $N / R$ \\
\hline & USA & INT & Consulting & 400 & $\mathrm{NS} / \mathrm{NC}$ & 500 & 15 & No & $N / R$ \\
\hline $\begin{array}{l}\text { La Nación } \\
\text { Michael }\end{array}$ & ARG & INT & Media & & & & & Yes & No \\
\hline Page Intl & EU & INT & $\begin{array}{l}\text { Consulting } \\
\text { Mass }\end{array}$ & 1595 & & 4100 & & Yes & $N / R$ \\
\hline Molinos & ARG & INT & $\begin{array}{c}\text { Consumption } \\
\text { Mass }\end{array}$ & 2100 & 2100 & $\begin{array}{l}5000 \\
2830\end{array}$ & 5000 & Yes & Yes \\
\hline Nestlé & EU & INT & Consumption & 340000 & 565 & $\begin{array}{c}00 \\
4000\end{array}$ & 1900 & Yes & Yes \\
\hline Nextel & USA & INT & Telco. & 32500 & $\begin{array}{c}202 \\
\text { America - }\end{array}$ & 0 & & Yes & No \\
\hline Nike & USA & INT & Sports & 18600 & USA) & $0+$ & & Yes & Yes \\
\hline $\begin{array}{l}\text { OSDE } \\
\text { Ostrillón }\end{array}$ & ARG & NAC & Health & & & 3500 & 3500 & Yes & No \\
\hline $\begin{array}{l}\text { SA } \\
\text { Pan Am. }\end{array}$ & ARG & NAC & Manufacturing & $\mathrm{N} / \mathrm{C}$ & $\mathrm{N} / \mathrm{C}$ & $\mathrm{N} / \mathrm{C}$ & $\mathrm{N} / \mathrm{C}$ & $N / R$ & $N / R$ \\
\hline $\begin{array}{l}\text { Energy } \\
\text { LLC } \\
\text { Peugeot }\end{array}$ & EU & INT & Energy & 3291 & & $\begin{array}{l}1800 \\
2010\end{array}$ & & Yes & No \\
\hline Citroën & EU & INT & Automotrve & 76000 & 2000 & 00 & 6000 & Yes & No \\
\hline
\end{tabular}

\footnotetext{
${ }^{3}$ All the information referred to the fiscal year prior to the survey. These vary in accordance with each firm's balance sheet closing. In the majority of the cases, the information related to 2008-2009 years.
} 
INDEPENDENT JOURNAL OF MANAGEMENT \& PRODUCTION (IJM\&P)

http://www.ijmp.jor.br

v. 5, n. 3, June - September 2014

ISSN: 2236-269X

DOI: 10.14807/ijmp.v5i3.181

\begin{tabular}{|c|c|c|c|c|c|c|c|c|c|}
\hline $\begin{array}{l}\text { Procter \& } \\
\text { Gamble }\end{array}$ & USA & INT & \begin{tabular}{|c|} 
Mass \\
Consumption
\end{tabular} & 79000 & 625 & $\begin{array}{c}1100 \\
00\end{array}$ & 850 & Yes & Yes \\
\hline $\begin{array}{l}\text { De Maiz } \\
\text { Roemmers }\end{array}$ & USA & INT & Agriculture & $\mathrm{N} / \mathrm{C}$ & & 700 & 700 & Yes & $N / R$ \\
\hline $\begin{array}{l}\text { SAICF } \\
\text { Russell }\end{array}$ & ARG & NAC & Lab. & 260 & 260 & 1100 & 1100 & Yes & $N / R$ \\
\hline $\begin{array}{l}\text { Reynolds } \\
\text { SK }\end{array}$ & USA & INT & Consulting & & & 1000 & & $N / R$ & $N / R$ \\
\hline $\begin{array}{l}\text { Tecnología } \\
\text { SK }\end{array}$ & ARG & NAC & IT & 4 & 4 & 40 & 40 & No & $N / R$ \\
\hline $\begin{array}{l}\text { Tecnología } \\
\text { SA } \\
\text { Stanton }\end{array}$ & ARG & NAC & IT & 2 & 2 & 40 & 40 & No & $N / R$ \\
\hline $\begin{array}{l}\text { Chase } \\
\text { Swiss }\end{array}$ & USA & INT & Consulting & 63,4 & 5,8 (Región) & 270 & 8 & No & No \\
\hline $\begin{array}{l}\text { Medical } \\
\text { SA } \\
\text { Telecom }\end{array}$ & ARG & NAC & $\begin{array}{l}\text { Health \& } \\
\text { Insurance }\end{array}$ & 783 & 773 & $\begin{array}{l}6640 \\
1800\end{array}$ & 6593 & Yes & $N / R$ \\
\hline Arg. SA & EU & INT & Telco. & 59000 & 3000 & $\begin{array}{c}00 \\
5230\end{array}$ & 14000 & Yes & No \\
\hline Telmex & MEX & INT & IT & 9100 & 120 & $\begin{array}{c}0 \\
2100\end{array}$ & 700 & Yes & No \\
\hline Tetra pack & EU & INT & Manufacturing & 13 & & 0 & 410 & Yes & No \\
\hline $\begin{array}{l}\text { Unitán } \\
\text { Zurich }\end{array}$ & ARG & INT & $\begin{array}{l}\text { Chemistry } \\
\text { Financ. \& }\end{array}$ & 34 & & $\begin{array}{c}540 \\
5800\end{array}$ & 540 & $\mathrm{~N} / \mathrm{R}$ & $N / R$ \\
\hline Argentina & EU & INT & Insurance & & 775 & 0 & 500 & Yes & No \\
\hline
\end{tabular}

